\title{
Assessing the Influence of Drainage Pipe Removal on Wetland Hydrology Restoration: A Case Study
}

\author{
Phillipe Vidon and Andrew P. Smith
}

\begin{abstract}
In this study, we assessed the restoration of a riparian wetland in a moderately incised glacial till valley of the Midwest where drainage pipes were either removed or disabled in 2000 and 2004. The study determined whether wetland hydrology was restored at the site and whether former drainage pipe locations still influenced wetland hydrology after restoration ended. Water table level measurements in 2004 and 2005 indicate that wetland hydrology has been restored in areas of the riparian zone with poorly drained loamy soil. These areas are characterized by an average water table depth of $10 \mathrm{~cm}$ below ground surface (BGS) for approximately six months of the year and a water level above $30 \mathrm{~cm}$ BGS for at least 14 consecutive days during the growing season. High-resolution water table measurements during and after precipitation events did not indicate that former drainage pipe locations affect the hydrology of the site either by allowing a quick water table drawdown or by acting as preferential conduits for groundwater during precipitation events. Overall, data indicate that wetland hydrology was restored and that the technique of cutting the drainage pipes into several sections or removing them by hand and compacting the disturbed soil back into place without adding any extra material was an appropriate restoration technique for this site.
\end{abstract}

Keywords: drainage, hydrology, Indiana, precipitation events, restoration, wetland

W etlands are critical ecotones between terrestrial and aquatic systems because they have a high level of biodiversity, provide critical habitat for many plants and animals, and are important in the maintenance of water quality (Andersen 2004). They are active zones of interaction between surface and groundwater, and help stabilize water supplies by mitigating the effect of floods and drought on surrounding ecosystems (Mitsch and Gosselink 2000). Nevertheless, between 1780 and the mid-1980s, wetland losses reached $53 \%$ for the lower 48 states and as high as $87 \%$, $89 \%$, and $90 \%$ in Indiana, Iowa, and Ohio, respectively (Mitsch and Gosselink 2000). In addition, excess losses of nutrient from the Mississippi River

Ecological Restoration Vol. 26, No. 1, 2008 ISSN 1522-4740 E-ISSN 1543-4079 (C)2008 by the Board of Regents of the University of Wisconsin System. drainage basin have been linked to the development of the "dead zone" in the Gulf of Mexico (Goolsby 2000). Mitsch et al. (2001) suggest that between 210,000 ha and 530,000 ha of wetlands should be restored or created in the Mississippi Basin to reduce hypoxia in the Gulf of Mexico. Hence, there is a critical need to restore existing wetlands or create new ones in many states in the Mississippi drainage basin, especially in states where high wetland losses and large nutrient exports have been documented.

Several studies have focused on the effect of wetland restoration on solute movement (Baird and Gaffney 2000), methane and $\mathrm{CO}_{2}$ gas fluxes (Van den Bos 2003), or nitrate attenuation (Sidle et al. 2000) among other topics. However, while many studies of wetland hydrology have been conducted (Schot and Wassen 1993, Hunt et al. 1998, 1999a, 1999b, Winter 1992, 2000), few have addressed the effect of various wetland restoration techniques on the basic hydrological functioning of restored or reestablished wetlands. Studying the hydrological functioning of wetlands after restoration is critical in order to assess wetland restoration and to develop effective restoration practices. Because hydrology affects species biodiversity, primary productivity, organic matter accumulation, and nutrient cycling in wetland systems, successful wetland restoration must begin with the restoration of wetland hydrology (Mitsch and Gosselink 2000). Restoration also includes the removal of invasive species and the introduction of native wetland plants, but this can be achieved only after wetland hydrology has been restored.

In this study, we examined the hydrological functioning of a restored riparian wetland in a glacial till valley of the Midwest where approximately $380 \mathrm{~m}$ of drainage pipes were removed or disabled in 2000 and 2004 in order 
to restore wetland hydrology. The two primary objectives of this study were to determine whether wetland hydrology was restored and whether former drainage pipe locations still have an effect on wetland hydrology two years after restoration ended. A secondary objective was to determine whether the restoration technique of cutting drainage pipes into several sections or removing the drainage pipes by hand and compacting the disturbed soil back into place without adding extra material was an appropriate restoration technique for this site. The effect of simply removing or disabling drainage pipes on wetland hydrology remains poorly documented. Even after drainage pipe removal, former drainage pipe locations may act as preferential conduits for groundwater, owing to soil disturbance during drainage pipe removal, and continue to alter wetland hydrology years after restoration took place (R. Barr, Indiana University, pers. comm.). If former drainage pipe locations are filled with fine-texture soil, this soil may act as a barrier and negatively affect the natural hydrology of the site.

\section{Site Description}

The riparian wetland we studied is part of the Scott Starling Nature Sanctuary and is located in a moderately incised till valley (15-20 $\mathrm{m})$ in the Tipton Till Plain along Fishback Creek in Central Indiana near Indianapolis (Figure 1a). Till thickness is approximately $50-55$ $\mathrm{m}$ in the upland and approximately $20-25 \mathrm{~m}$ in the valley bottom where the riparian wetland is located. Two layers of till have been identified at the study site. The lower unit is preWisconsinian in age and the upper Trafalgar till unit is of Wisconsinian age (Harrison 1963). Typical till in this area consists of coarse silt to fine sand and is high in carbonates owing to the limestone and dolomite bedrock eroded by glacial meltwater streams (Harrison 1963). Seeps are observed along the valley at the

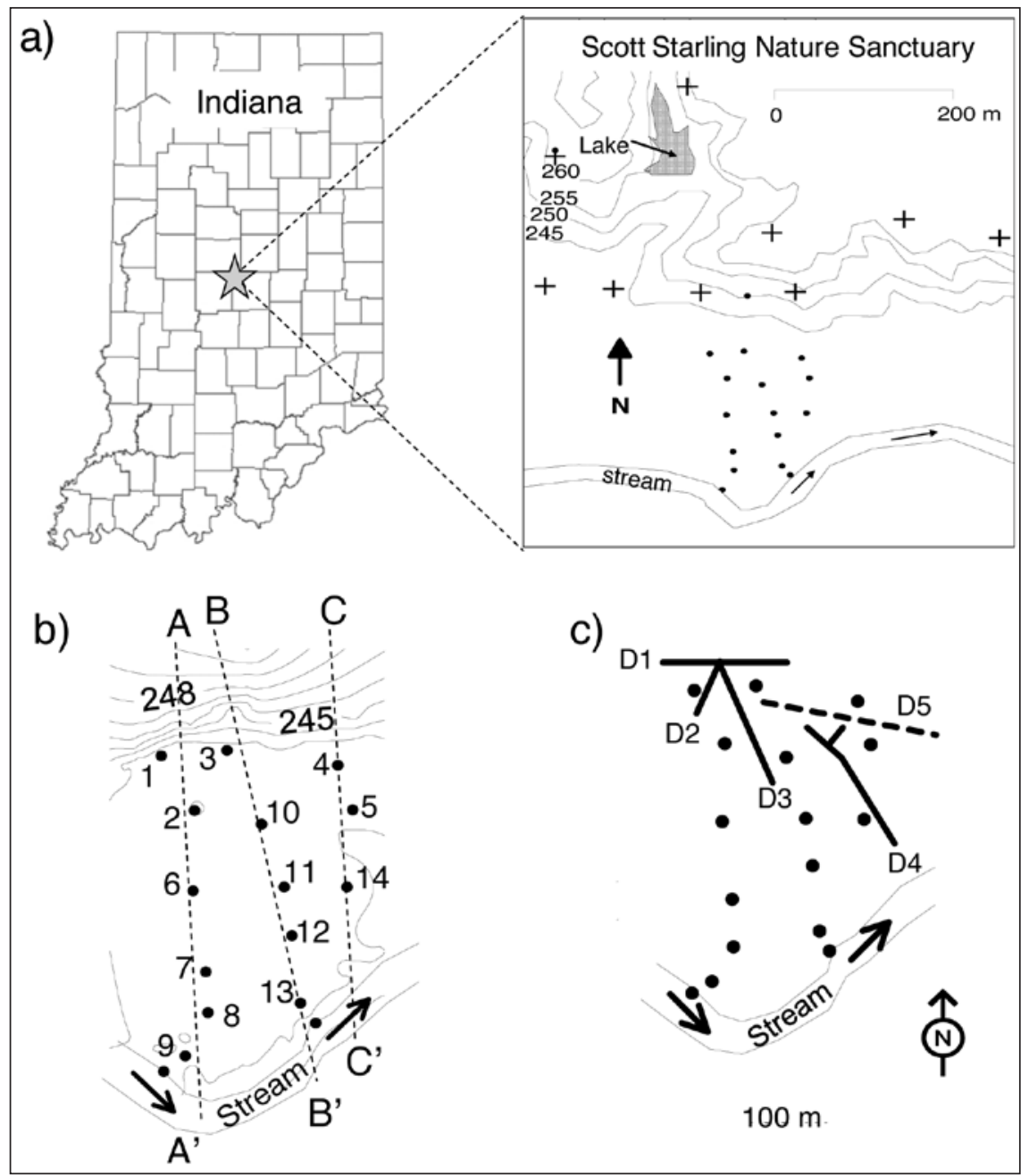

Figure 1. Site description: a) Indiana and local topography with elevation $(\mathrm{m})$ above sea level indicated by $5-\mathrm{m}$ contour intervals and location of houses in the upland by (+); b) riparian zone topography (1-m contour intervals) and piezometer and well locations (numbers 1-14), unlabelled black dots indicate stream stage measurement points, lines $A A^{\prime}, B^{\prime}$ ' and $C C^{\prime}$ correspond to the three well and piezometer transects; and c) locations of former drainage pipes (D1-D5), solid lines indicate drainage pipes that were removed, dashed lines represent disabled drainage pipes.

interface between the two till units (approximately $8 \mathrm{~m}$ above the riparian wetland) and contribute water to the riparian wetland complex. This setting is common in many glacial till valleys of the Midwest (Thompson et al. 1992). Both till units were incised by glacial meltwater outbursts during the Wisconsinian Epoch. Fishback Creek, which flows through the central portion of the study site, is a remnant of those ancient streams. A thin (approximately $2 \mathrm{~m}$ ) layer of alluvium overlying the lower till unit restricts flow to the first $2 \mathrm{~m}$ of the soil profile and forms the riparian zone between the stream and the slope bottom. Topography in the study area is characterized as steep concave with a flat area directly adjacent to the stream (Figures 1a and 1b).

Annual precipitation at the site is $104 \mathrm{~cm} / \mathrm{y}$ with approximately 6.9 $\mathrm{cm}$ falling as snow between November and March (NOAA 2005). The mean annual temperature is $11.4^{\circ} \mathrm{C}$ with a mean January temperature of $-3.1^{\circ} \mathrm{C}$ and a mean July temperature of $24.1^{\circ} \mathrm{C}$. Through the duration of the study, precipitation amounts were $6 \%$ wetter than the 30-year norm (NOAA 2002). The growing season, defined as the first and last freeze date over a 30-year period, extends from April 10 until October 28 at this site (NOAA 2005). 


\section{Site Restoration History}

The riparian zone studied was artificially drained and cultivated until 1991. Although crops were not grown on the site between 1991 and 1999 , tile drains remained active and prevented the return of wetland conditions. In 1999, restoration efforts began to restore the hydrology of the site with the removal of approximately $150 \mathrm{~m}$ of drainage pipes $(10.1 \mathrm{~cm}$ in diameter, $60 \mathrm{~cm}$ deep) in 2000 and approximately $230 \mathrm{~m}$ of pipes in 2004. Drainage pipe locations were determined through extensive soil probing at the site; however, although drainage pipes were clearly active at the time the restoration took place, it was not possible to determine with precision where the drainage pipes were draining into the stream. Only known drainage pipe locations are shown, therefore, on Figure 1c.

We determined the general topography of the area using a digital elevation model. Detailed topography of the study site and immediate upland area were determined using a total station (TC 605L Surveying TPS, Leica Geosystems). Figure 1c indicates the location of the drainage pipes that were removed or disabled at the site. Drainage pipes at locations D1-D3 were removed from the site in 2000; pipes at location $\mathrm{D} 4$ were removed in 2004. The pipes were removed with a shovel to minimize soil disturbance, and soil displaced during drainage pipe removal was compacted back into place simply by stepping on it without adding any material. Drainage pipe D5 was disabled by cutting it into several pieces in 2004. Soil probing of the entire site did not reveal any other drainage pipe. As part of the larger restoration effort for the nature sanctuary, non-native plant species were removed and native vegetation was planted each year between 1999 and 2004.

\section{Methods}

We established three monitoring transects perpendicular to stream flow. Along the transects we installed a total of 14 monitoring wells (each one composed of 5-cm diameter PVC pipe at 130 to $170 \mathrm{~cm}$ deep and screened their entire length) and 14 piezometer nests (made of 1.74-cm diameter PVC with a 20-cm slotted end). In each nest, 3 piezometers were installed using a hand auger at $50 \mathrm{~cm}, 100 \mathrm{~cm}$, and between 130 and $190 \mathrm{~cm}$ deep (Figure 1c). A nylon mesh sleeve was placed over screened intervals to minimize obstruction of wells and piezometers by fined-grained particles. Holes were filled with sand along the screened intervals and a bentonite clay seal was applied at ground level to prevent contamination from surface runoff (Sanders 1998, Vidon and Hill 2004b). The deepest piezometer at each nest was finished in the gravel layer overlying the till or near the till surface. Riparian soil textures were determined during well and piezometer installation first by hand-texturing in the field and later by dry sieving of soil samples in the laboratory to separate the sand fraction from the clay/silt fraction (Casey and Simpson unpub. data).

Between November 2004 and March 2006, we monitored water levels in the piezometers and wells approximately once a month in the summer and winter, and twice a month during the spring and fall when most large changes in water level occurred. On dates when no water was present in the monitoring well, the water level from the shallowest piezometer with water was used to represent the water table elevation. In addition, water level loggers (YSI) were installed in wells 1,2 , $5,7,9,11,13$, and 14 from February 2006 until July 2006 to monitor water level across the riparian wetland on a 15-minute time interval. Biweekly water table measurements allowed us to determine areas of the riparian zone with wetland hydrology, whereas high resolution water table data during and after precipitation events allowed us to identify areas of preferential flow in the wetland or areas of quick water table drawdown in the days following precipitation in relation to former drainage pipe locations.

We used the Surfer 7 mapping program (Golden Software, Inc.) to produce water table elevation maps for seven storm events between February and June 2006. In order to reduce water level interpolation error between wells equipped with level loggers, the water level in wells that were not equipped with level loggers was modeled during storm events based on water levels recorded for wells 1, 2, $5,7,9,11,13$, and 14 . Using manual water level measurements recorded in all wells between November 2004 and March 2006, a correlation matrix was used to pair wells with level loggers (wells 1, 2, 5, 7, 9, 11, 13, 14) to wells without level loggers (wells 3 , $4,6,8,10,12)$. Wells with the highest correlation coefficient were paired. Water levels in wells 3, 4, 6, 8, 10, and 12 were then calculated using a simple linear regression for each pair of wells for selected precipitation events. Daily precipitation data for the study period was recorded at Eagle Creek Airpark, located $6.4 \mathrm{~km}$ from the study site. Oxido-reduction potential (ORP) was measured in the field on 16 dates between January 2005 and March 2006 in each groundwater well as an indicator of the soil redox state using a multi-parameter probe (YSI 600XLM-SV) (Mitsch and Gosselink 2000).

\section{Results}

\section{Soil characteristics and detailed riparian topography}

The riparian zone soils range in texture from clay to coarse sand and gravel but are primarily characterized as loam and sandy loam near the surface with an increasing amount of gravel (15-60\%) at depth between wells 6 and 9 (Figure 2a). The soil profile shown for cross-section AA' in Figure 2a is representative of soil 


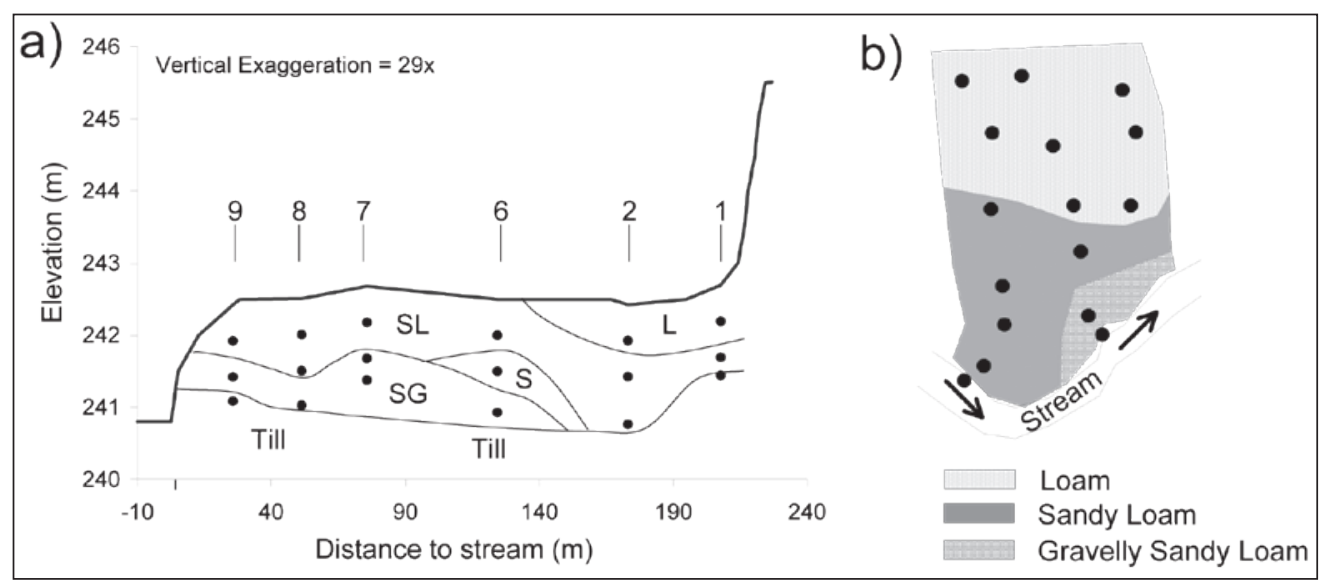

Figure 2. Soil characteristics: a) vertical cross section along transect AA' showing riparian lithology, dots represent piezometer slot zones; S = sand; SL = sandy loam; L = loam, SG = sand and gravel; b) planar view of dominant surficial soil characteristics.

profiles identified for cross sections BB' and CC', where the gravel layer at depth extends from the stream to wells 12 and 14, respectively. Loamy soil dominates near the surface in the first half of the riparian zone near the slope bottom (wells 1, 2, 3, 4, 5, 10, 11, $14)$, whereas sandy loam dominates closer to the stream (wells 6, 7, 8, 9, 12, 13) (Figure 2b). Field observations and data collected during piezometer installation allowed us to estimate the till depth at approximately $1.7-2.0 \mathrm{~m}$ below ground surface (BGS) in the riparian zone. Soil saturated hydraulic conductivity measurements indicate an average soil hydraulic conductivity $\left(\mathrm{K}_{\mathrm{S}}\right)$ of $63 \mathrm{~cm} / \mathrm{d}(\mathrm{SD}=127)$ for piezometers located in areas of the riparian zone where loamy soil dominates near the surface (piezometer nests $1,2,3,4,5,10,11,14)$ and an average $\mathrm{K}_{\mathrm{S}}$ of $132 \mathrm{~cm} / \mathrm{d}(\mathrm{SD}=204)$ for piezometers where sandy loam dominates near the surface. The average soil hydraulic conductivity in the gravelly sand layer at depth is $158 \mathrm{~cm} / \mathrm{d}$ (SD = 223) (data not shown).

The site has a general down-valley topographical gradient with a change in elevation between transect $\mathrm{AA}^{\prime}$ and $C^{\prime} C^{\prime}$ of approximately $40 \mathrm{~cm}$ over a 100-m distance (Figure 3). Contour lines also indicate a small depression (20 cm deep) near wells 1 and 3, and in the middle of the riparian zone in an area bordered by wells 2,10 , and 5 on the upland side and 6,11 , and
14 on the stream side (Figure 3). The point of lowest elevation is located between piezometers 5 and 14 .

\section{Water Table Fluctuations}

Two distinct hydrologic periods can be identified from well hydrographs (Figure 4). The first corresponds to winter and spring months during which the average water table depth for the entire riparian zone is $40 \mathrm{~cm}$ BGS. The second corresponds to summer and fall months during which the average water table depth is $122 \mathrm{~cm}$ BGS. In addition, two groups of wells emerge from analysis of Figure 4. During the high water table period, water levels in wells 1 and 2 (group 1) remain close to the surface (average water table depth is 10 cm BGS) and show very little response to precipitation, whereas wells $6,7,8$, and 9 (group 2) are more responsive to precipitation inputs (see shape of well hydrographs) with an average water level depth of $58 \mathrm{~cm} \mathrm{BGS} \mathrm{(Figure} \mathrm{4a).}$ During the low water table period, wells in both groups show similar responses to precipitation events; the average water table depth for group 1 is $119 \mathrm{~cm} \mathrm{BGS}$ and $127 \mathrm{~cm} \mathrm{BGS} \mathrm{for}$ group 2 wells.

Data for transect BB' (Figure $4 \mathrm{~b}$ ) and CC' (Figure 4c) indicate that wells $3,4,5,10$, and 11 behave similarly to wells 1 and 2 and therefore belong to group 1 . Wells 12 and 13 behave similarly to group 2 wells. Although the shape of the well hydrograph for well

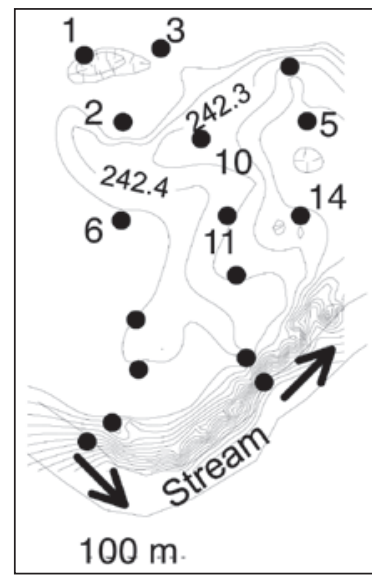

Figure 3. Detailed site topography with $0.1-\mathrm{m}$ contour intervals. Numbers 1, 2, 3, 5 , $6,10,11$, and 14 indicate well and piezometer locations.

14 is similar to group 1 hydrographs, the water level in well 14 is generally below $30 \mathrm{~cm}$. We considered, therefore, well 14 to be part of group 2. The correlation matrix (Table 1) indicates a strong linear relationship between water level in well 3 and water levels in wells 1 and $2\left(r^{2}=0.96\right)$. Well 4 behavior most resembles well $11\left(r^{2}\right.$ $=0.98)$, well 6 most resembles wells 2 and $11\left(r^{2}=0.99\right)$, well 8 correlates strongly with well $9\left(r^{2}=0.98\right)$, well 10 with wells 2 and $11\left(r^{2}=0.99\right)$, and well 12 with well $14\left(r^{2}=0.97\right)$. The linear relationships established between water levels in these wells were used to estimate the water level in wells $3,4,6,8,10$, and 12 during selected precipitation events.

\section{Groundwater oxido-reduction potential}

Data indicate a drop in redox potential from the $300 / 0 \mathrm{mv}$ range during the high water table period down to the $0 /-200 \mathrm{mv}$ range during the low water table period (June-September) for both groups 1 and 2 (Figure 5). However, redox values are generally lower during the low water table season for group 1 wells (average $=$ $-89 \mathrm{mv}$ ) than for group 2 (average = $-25 \mathrm{mv}$ ). During the high water table season, redox potential averages 91 $\mathrm{mv}$ in group 1 wells and $136 \mathrm{mv}$ in group 2 . 


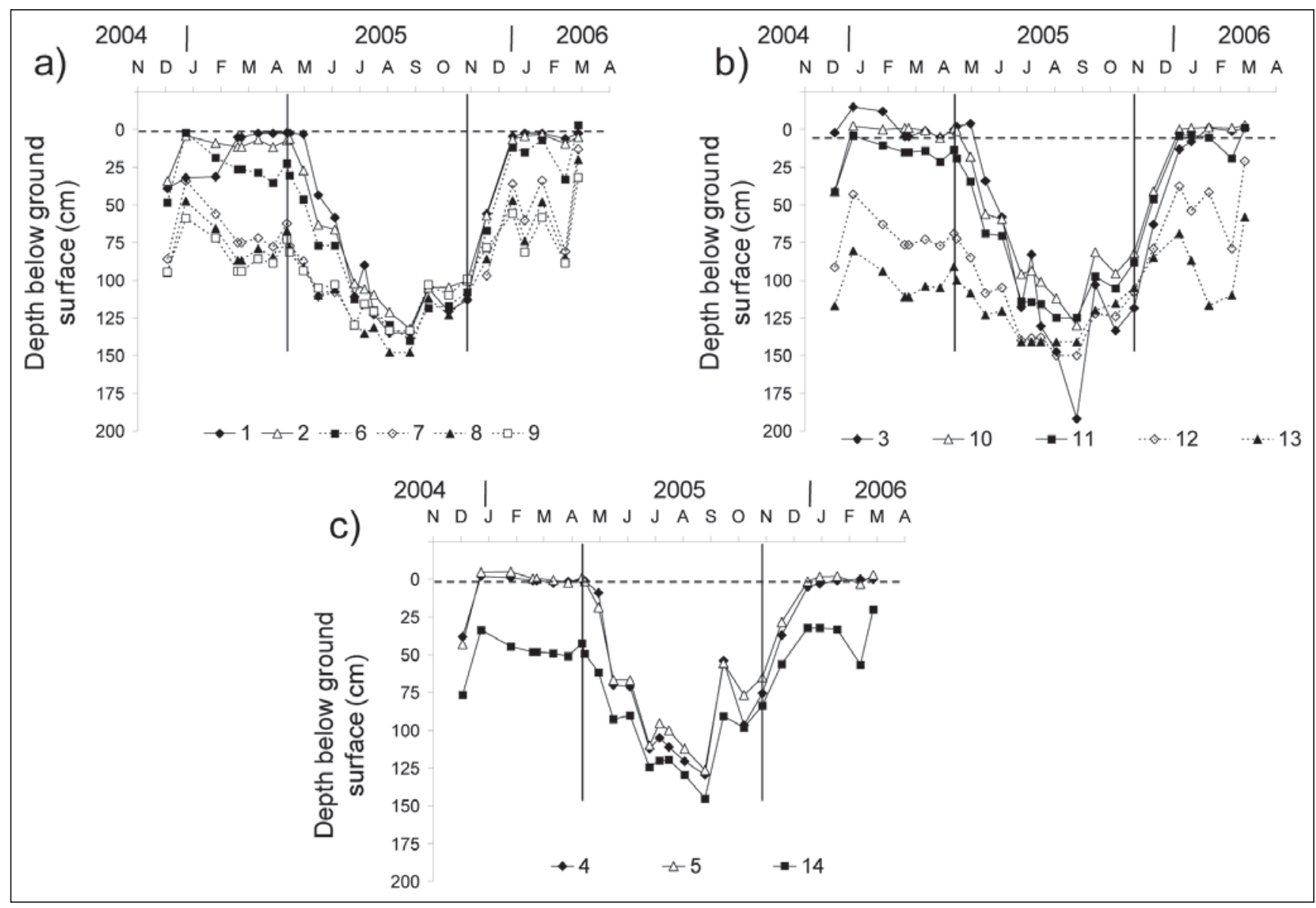

Figure 4. Water table depth below ground surface (cm) between November 2004 and April 2006: a) wells 1, 2, 6, 7, 8, 9 (transect AA'); b) wells 3, 10, $11,12,13$ (transect $\left.B B^{\prime}\right) ; c$ ) wells 4, 5, 14 (transect $C^{\prime}$ ). Dashed lines indicate ground surface; vertical black lines indicate the beginning and the end of the growing season (April 10-October 28).

Table 1. Water level correlation matrix for wells 1-14 $(n=26)$ between November 2004 and March 2006. Well numbers in bold indicate wells that were equipped with a level logger from February to July, 2006. Pearson correlation coefficients $\left(\rho_{\mathrm{xy}}\right)$ underlined in bold indicate well pairings used to determine the water level in wells 3, 4, 6, 8, 10, and 12 during precipitation events during the February-July 2006 period based on water levels in wells 1, 2, 5, 7, 9, 11,13 , and 14 equipped with water level loggers.

\begin{tabular}{|c|c|c|c|c|c|c|c|c|c|c|c|c|c|c|}
\hline Wells & 1 & 2 & 3 & 4 & 5 & 6 & 7 & 8 & 9 & 10 & 11 & 12 & 13 & 14 \\
\hline 1 & - & & & & & & & & & & & & & \\
\hline 2 & 0.97 & - & & & & & & & & & & & & \\
\hline 3 & $\underline{0.96}$ & $\underline{0.96}$ & - & & & & & & & & & & & \\
\hline 4 & 0.94 & 0.97 & 0.93 & - & & & & & & & & & & \\
\hline 5 & 0.93 & 0.96 & 0.92 & 0.99 & - & & & & & & & & & \\
\hline 6 & 0.94 & $\underline{0.99}$ & 0.94 & 0.95 & 0.95 & - & & & & & & & & \\
\hline 7 & 0.84 & 0.90 & 0.83 & 0.86 & 0.87 & 0.95 & - & & & & & & & \\
\hline 8 & 0.83 & 0.89 & 0.83 & 0.89 & 0.90 & 0.94 & 0.96 & - & & & & & & \\
\hline 9 & 0.76 & 0.82 & 0.77 & 0.84 & 0.86 & 0.88 & 0.93 & $\underline{0.98}$ & - & & & & & \\
\hline 10 & 0.97 & 0.99 & 0.96 & 0.98 & 0.98 & 0.98 & 0.89 & 0.89 & 0.83 & - & & & & \\
\hline 11 & 0.95 & 0.99 & 0.94 & 0.98 & $\underline{0.98}$ & 0.99 & 0.93 & 0.92 & 0.87 & 0.99 & - & & & \\
\hline 12 & 0.87 & 0.92 & 0.86 & 0.92 & 0.93 & 0.96 & 0.96 & 0.99 & 0.97 & 0.93 & 0.96 & - & & \\
\hline 13 & 0.67 & 0.73 & 0.66 & 0.77 & 0.79 & 0.78 & 0.81 & 0.89 & 0.91 & 0.75 & 0.80 & 0.89 & - & \\
\hline 14 & 0.89 & 0.94 & 0.89 & 0.96 & 0.98 & 0.96 & 0.91 & 0.95 & 0.93 & 0.96 & 0.97 & 0.98 & 0.87 & - \\
\hline
\end{tabular}




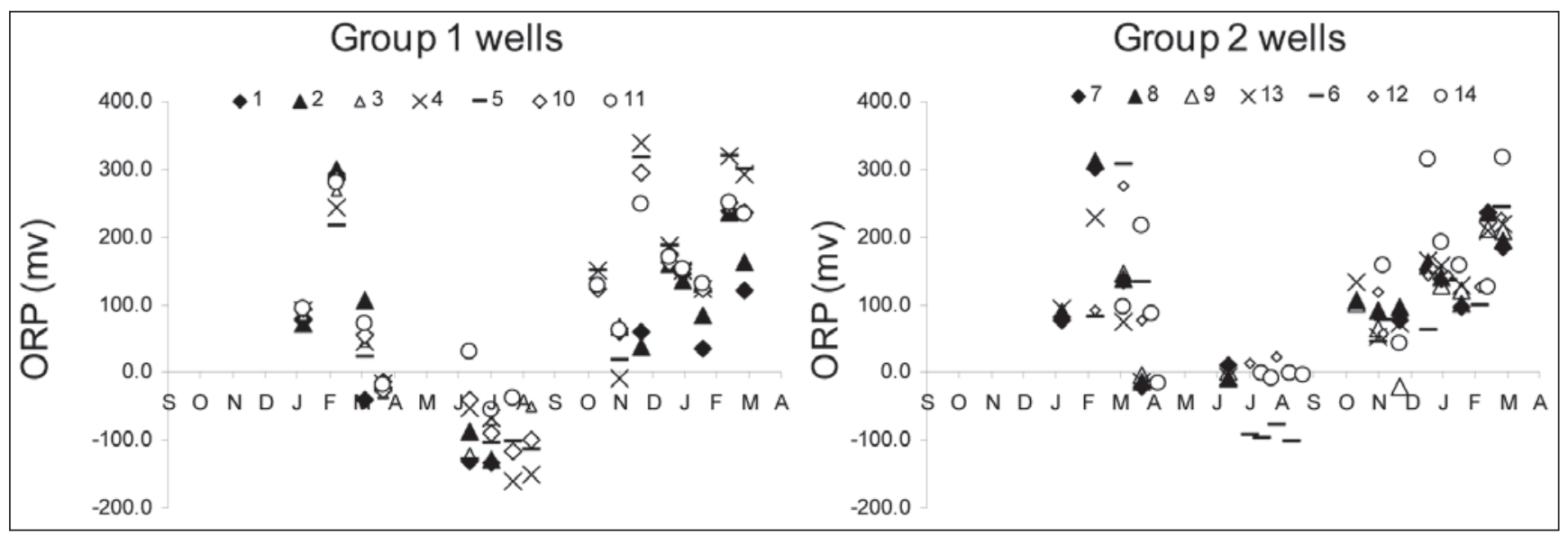

Figure 5. Groundwater oxido-reduction potential (ORP) (mv) for wells 1, 2, 3, 4, 5, 10, and 11 (group 1, left) and wells 6, 7, 8, 9, 12, 13, and 14 (group 2, right) between January 2005 and March 2006.

\section{Water table response to precipitation events}

Data for wells 1, 2, 11, and 13 from February to June, 2006, indicate a drop in water table elevation from the slope bottom (well 1) toward the stream (well 13) and illustrate the typical water table response to precipitation events at the site (Figure 6). Water table fluctuations are small in well $1(<10 \mathrm{~cm})$ and increase towards the stream. With the exception of two storms in March and April, flow reversals (i.e., stream-to-riparian zone water table gradient, Duval and Hill 2006) do not occur at the site. Well hydrographs indicate that group 2 wells (11 and 13) are more responsive to precipitation events than group 1 wells located closer to the slope bottom.

Water table fluctuations were studied in detail for two storms on April 10-28 (S1) (Figure 7) and May 23-June 1 (S2) (Figure 8). An additional five storms (storms S3 to S7) were also studied to determine the consistency of processes described in detail for storms S1 and S2 (Figure 9). Precipitation events studied ranged from $1.37 \mathrm{~cm}$ to $11.7 \mathrm{~cm}$ of rain over 2-6 d periods.

Before the beginning of storm S1 on April 14 (Figure 7a), water flowed mainly perpendicular to the stream with a slight down valley gradient. Approximately 27 hours into the

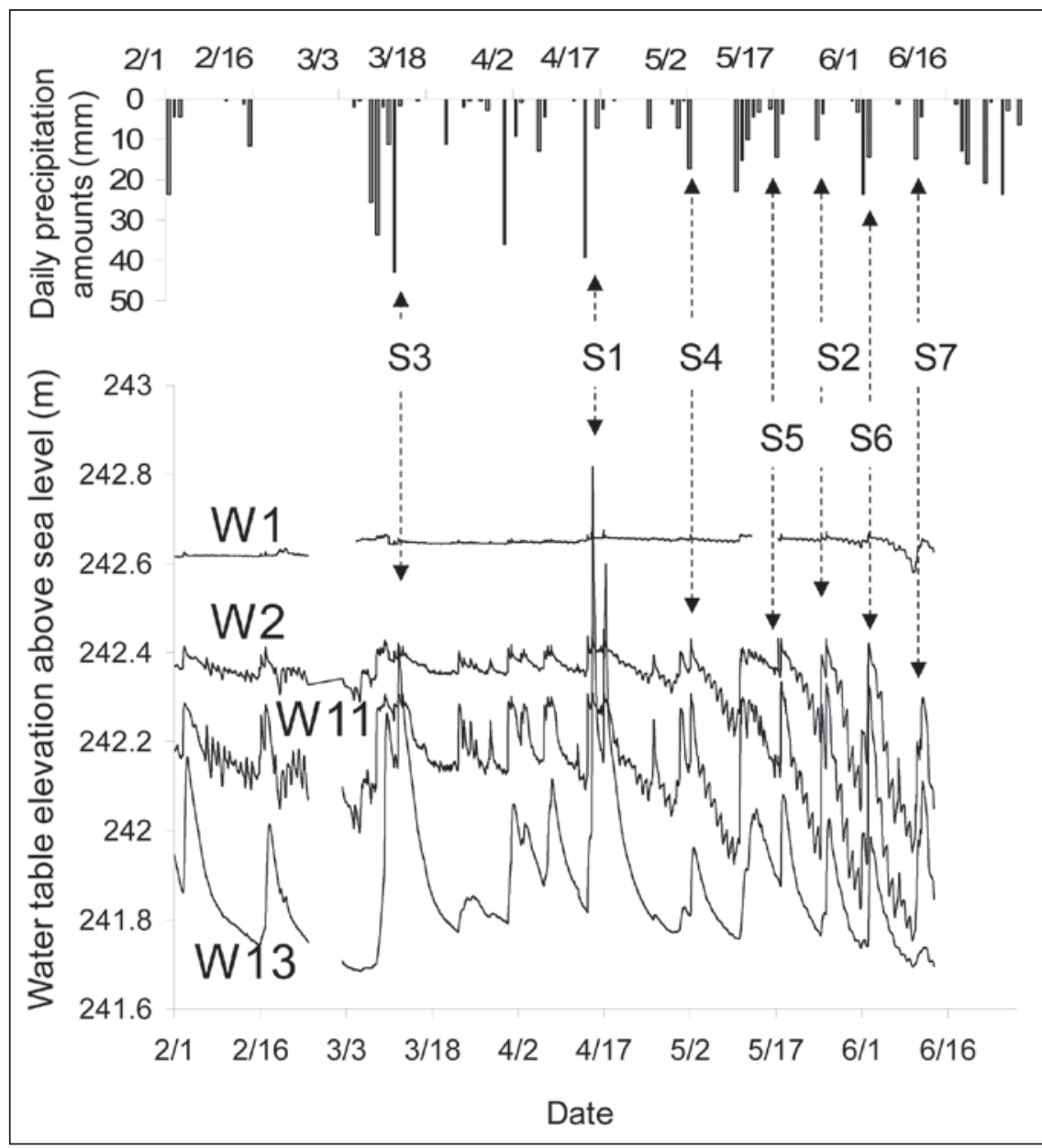

Figure 6. Daily precipitation $(\mathrm{mm})$ and water table elevation (15-min intervals) in meters above sea level for wells 1, 2, 11, and 13 between February and June, 2006. Letters S1-S7 indicate the precipitation events studied. Storm $S 1$ produced $4.90 \mathrm{~cm}$ total rain $(3.94 \mathrm{~cm}$ on April 14, $0.71 \mathrm{~cm}$ on April 16, and $0.25 \mathrm{~cm}$ on April 17). Storm S2 was smaller but more typical and produced 1.37 $\mathrm{cm}$ total rain $(1.02 \mathrm{~cm}$ on May 24 and $0.35 \mathrm{~cm}$ on May 25). Storms S3-S7 produced totals of 11.7 $\mathrm{cm}(\mathrm{S} 3), 2.54 \mathrm{~cm}(\mathrm{~S} 4), 2.05 \mathrm{~cm}$ (S5), $4.14 \mathrm{~cm}$ (S6), and $1.96 \mathrm{~cm}(\mathrm{~S} 7)$. 


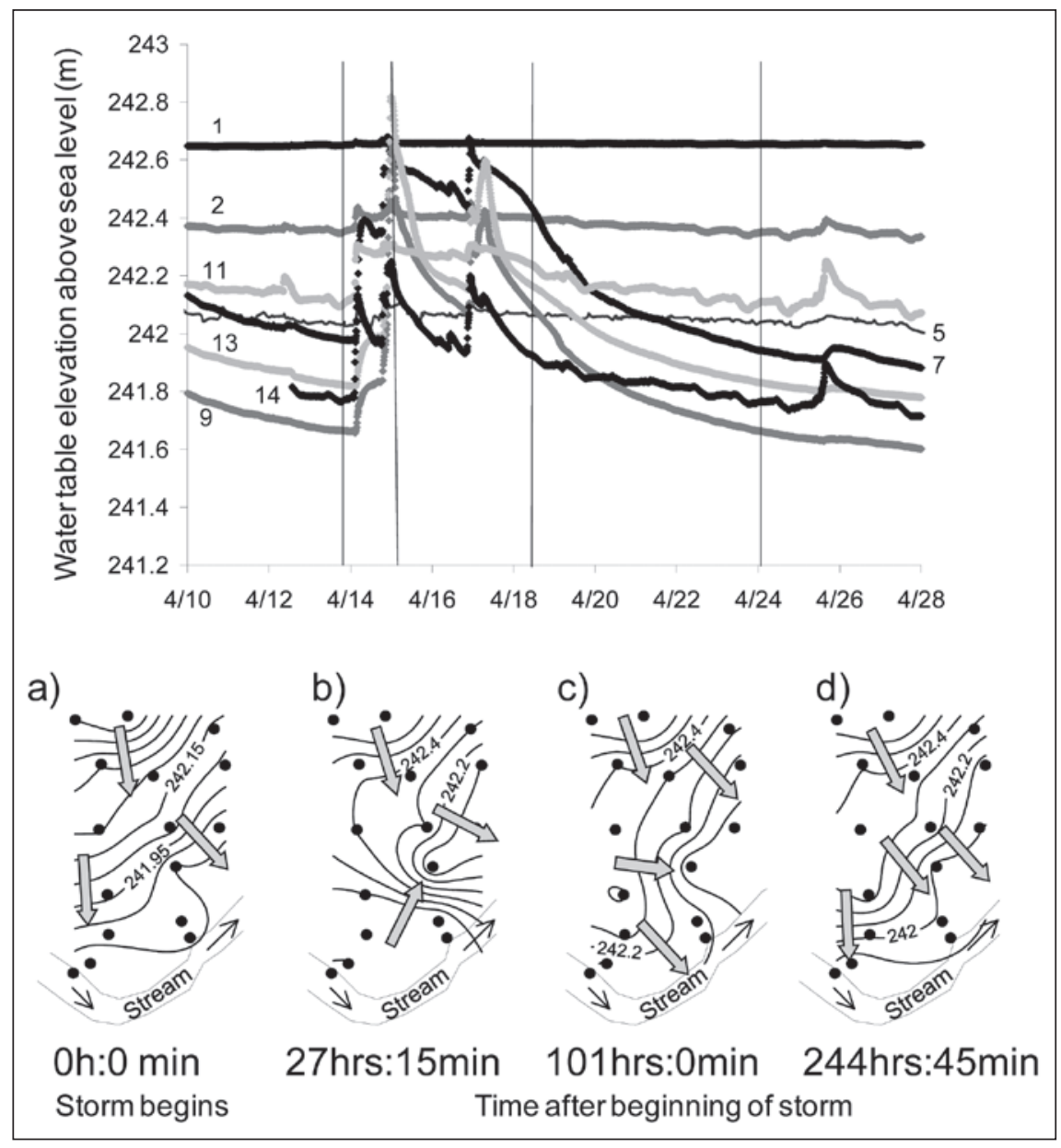

Figure 7. Well hydrographs for wells 1, 2, 5, 7, 9, 11, 13, and 14 (top) and water table maps (a-d) with 0.1-m contour intervals for storm S1 between April 10 and April 28, 2006. Vertical lines on the hydrographs indicate the times of the corresponding maps. Small arrows indicate the general direction of flow; arrow size is not proportional to magnitude of flow.

storm, a strong flow reversal was observed with a high water table near the stream (wells 9, 13, and 8) and flow toward the middle of the riparian zone. Nevertheless, a high water level near the slope bottom (wells 1, $2,3)$ continued to force water toward the middle of the riparian zone where a strong down-valley gradient had developed (Figure 7b). This condition occurred again on April 17 as the water table level in the riparian zone reached its second peak (data not shown) before flow across the riparian zone progressively shifted back to pre-storm conditions 100 and 244 hours after the storm began (Figures $7 \mathrm{c}$ and $7 \mathrm{~d}$ ).

A slightly different water flow pattern occurred during storm S2 (Figure 8). A lateral flow dominated with a the slope bottom forcing water toward the middle of the riparian area with a strong downstream component. For storms S4 $(2.54 \mathrm{~cm}), \mathrm{S} 5(2.05 \mathrm{~cm})$, $S 6(4.14 \mathrm{~cm})$ and $S 7(1.96 \mathrm{~cm})$, flow direction in the riparian zone remained similar to pre-storm conditions as the water table rose and fell as described for storm S2.

\section{Discussion}

\section{Was wetland hydrology restored?}

The water table remains within $25 \mathrm{~cm}$ of the ground surface approximately 6 months of the year in the section of the riparian zone corresponding to group 1 (Figure 4). This section is located near the slope bottom where loamy soil dominates near the surface and where drainage pipes were removed or disabled in 2000 and 2004. In areas where sandy loam dominates and where gravel is present at depth, i.e., the area of the riparian zone near the stream (Figure 2b), the water table remains below $25 \mathrm{~cm}$ most of the time and below $60 \mathrm{~cm}$ during the growing season. No drainage pipes were found in this section of the riparian zone, which is consistent with the occurrence of naturally well-drained soil with a high percentage of gravel (15-60\%) and higher soil hydraulic conductivities at depth.

In addition to having sediments more conducive to transmitting water, these locations are also closest to the stream, which depresses the water table locally. Data suggest that near saturation conditions persist only in an area delimited by wells $1,4,6$, and 14 (i.e., areas distant from the stream and characterized by poorly drained loamy soil near the surface). The criterion used by the U.S. Army Corps of Engineers (1987) — water table within $30 \mathrm{~cm}$ of land surface consecutively for five percent of the growing seasoncan be used to evaluate which portions of the site might be considered jurisdictional wetland. Following this procedure, areas of the site where the water table remains above $30 \mathrm{~cm}$ BGS 


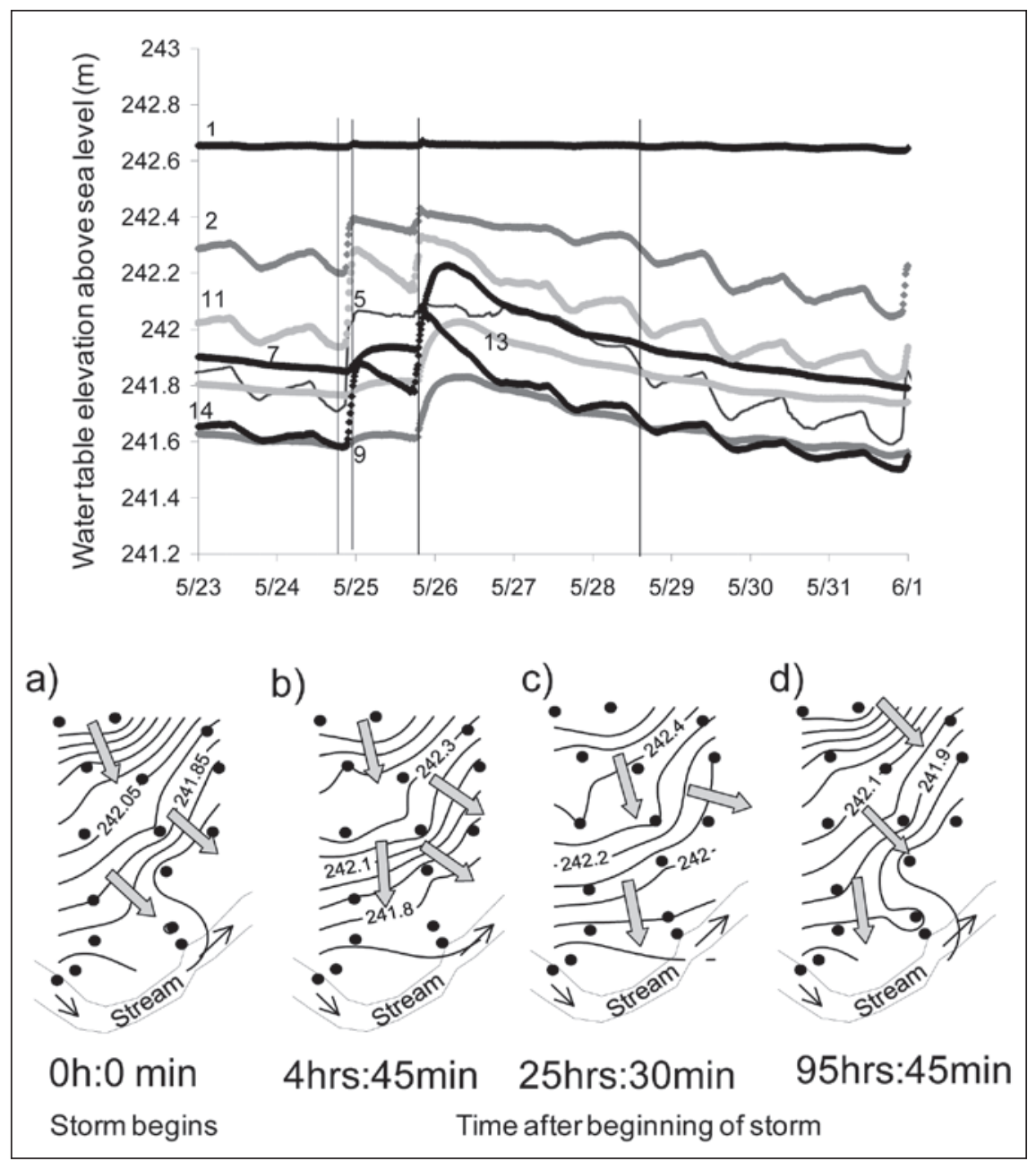

Figure 8. Well hydrographs for wells 1, 2, 5, 7, 9, 11, 13, and 14 (top) and water table maps (a-d) with 0.1-m contour intervals for storm S2 between May 23 and June 1, 2006. Vertical lines on the hydrographs indicate the times of the corresponding maps. Small arrows indicate the general direction of flow; arrow size is not proportional to magnitude of flow.

during 14 consecutive days during the growing season are considered as having wetland hydrological characteristics (Skaggs et al. 1994). Areas surrounding wells 1, 2, 3, 4, 5, 10, and 11 meet this criterion (Figure 10).

These findings are consistent with the hydrogeological setting of the site. Indeed, seeps are observed at the slope bottom, and drainage pipe D1 (Figure 1b) was stopping seep water from recharging the riparian wetland. Now that drainage pipes D1, D2, and D3 have been removed, seeps can help maintain a high water table in the naturally occurring wetland located near the slope bottom. Wells maintaining a high water table are those located in areas where poorly drained loamy soil is observed. Wells where
Oxidation-reduction potential measurements in groundwater during summer months also indicate typical saturated wetland soils, with an average ORP of $-89 \mathrm{mv}$ in the area of the riparian zone where wetland hydrology is observed and $-25 \mathrm{mv}$ in the remaining riparian zone. During the high water table period, ORP values typically vary between 0 and $300 \mathrm{mv}$ but generally remain below $250 \mathrm{mv}$ in most of the riparian site. As indicated by Mitsch and Gosselink (2000), an oxido-reduction potential of approximately $250 \mathrm{mv}$ is a threshold for denitrification to occur. These results suggest that denitrification is likely to occur at this site, provided that an adequate source of organic carbon and nitrate is available (Vidon and Hill 2004a). ORP data suggest, therefore, that the restoration restored biogeochemical conditions typical of wetland soils.

\section{Do former drainage pipe locations still affect wetland hydrology?}

High resolution water table elevation data were used to identify areas of preferential flow in the riparian zone and areas where rapid water table drawdowns occurred after precipitation events. We analyzed water table fluctuation data for storms S1-S7 with respect to soil texture, topography, and former drainage pipe locations to determine whether former drainage pipe locations still affect wetland hydrology two years after wetland restoration ended.

Changes in water table elevation during storm S1, which was the second largest storm of the FebruaryJune 2006 period and generated the largest water table response (Figure 6), indicate a water table gradient toward the middle of the riparian zone with a strong downstream component near wells 5, 14, and 12 during the period when the water table is the highest. Twenty-seven hours into the storm (maximum water table height), the flow reversal near the stream occurs, while a high water table near the slope bottom, likely due to the accumulation 


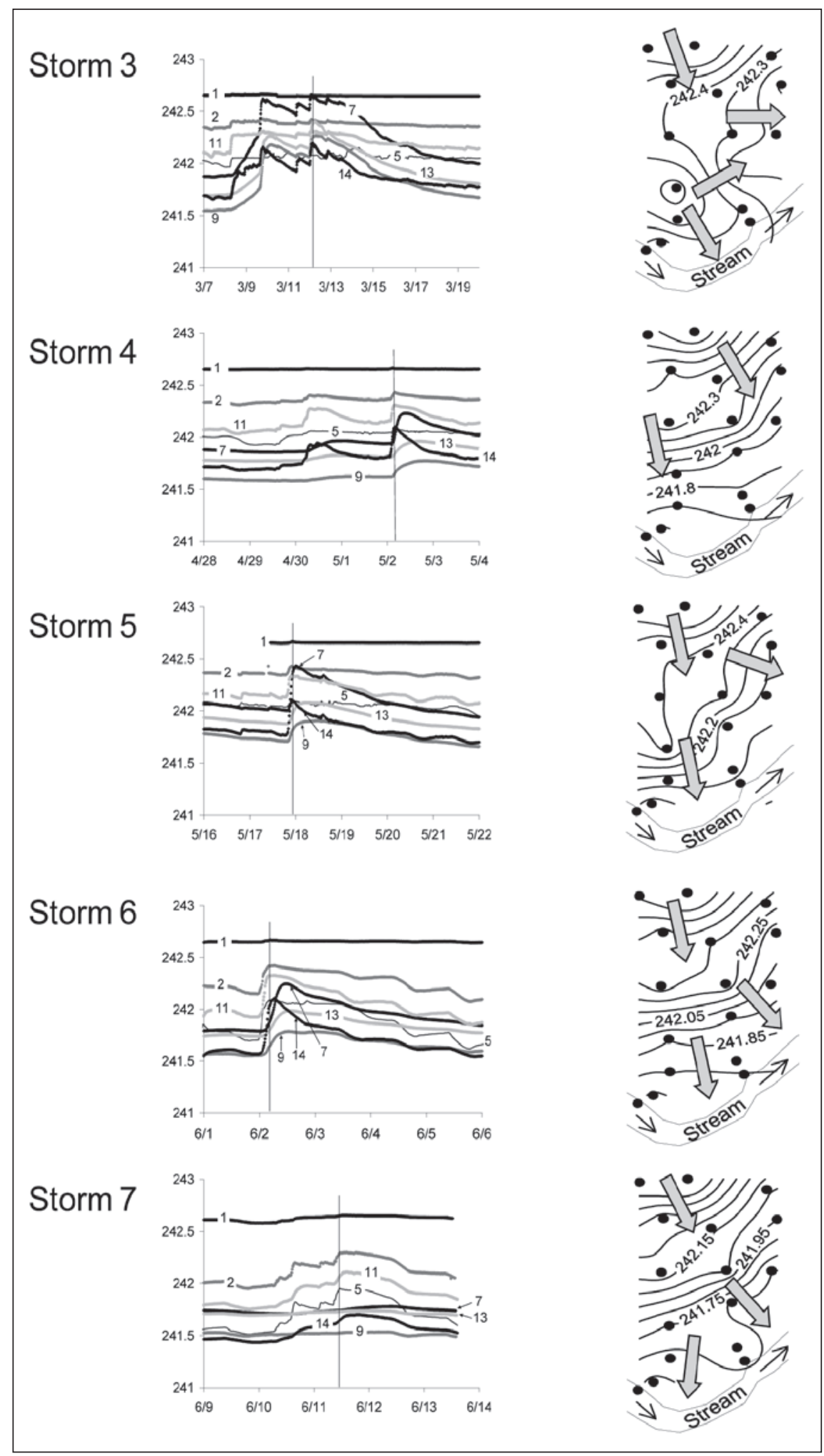

Figure 9. Well hydrographs for wells 1, 2, 5, 7, 9, 11, 13, and 14 (left) and water table maps with 0.1-m contour intervals (right) for storms S3-S7. Vertical lines on the hydrographs indicate the times of the corresponding maps. Small arrows indicate the general direction of flow; size is not proportional to magnitude of flow. During storm $S 3(11.7 \mathrm{~cm})$, a flow reversal occurred with a high water table near the stream and the slope bottom, forcing water toward the middle of the riparian area with a strong downstream component. During storms $S 4(2.54 \mathrm{~cm})$, S5 $(2.05 \mathrm{~cm})$, $S 6(4.14 \mathrm{~cm})$, and $S 7(1.96 \mathrm{~cm})$, flow direction in the riparian zone remained similar to pre-storm conditions as the water table rose and fell as described for storm S2. of hillslope runoff at that location, continues to force water toward the middle of the riparian zone. It appears that flow concentrates toward the middle of the riparian zone where a small depression naturally leads water downstream (Figure 3). This suggests that the small topographical depression observed in the middle of the riparian zone acts as a natural channel and allows water coming from both the hillslope and the stream to flow in a downstream direction. A similar groundwater flow pattern is observed for storm S3. Storms S3 and S1 were the two largest of the February-June 2006 period with 4.90 and $11.7 \mathrm{~cm}$ of rain over a 6 -day period.

For the smaller magnitude storms S2 and S4-S7 $(<4.14 \mathrm{~cm}$ and $<4$ days), a flow reversal and a strong down valley gradient toward the middle of the riparian zone and wells 5,12, 14 are not observed. This suggests that the flow patterns observed during storms S1 and S3 are likely storm-specific and typically occur for large and multiday precipitation events. Jung et al. (2004) observed a similar behavior in a riparian zone in England and showed that flow reversal can occur in a matter of days during large precipitation events. Moreover, changes in flowpath during storms are often three-dimensional rather that just in a direction perpendicular to the stream (Jung et al. 2004). In addition, well hydrographs during storms S1-S7 (Figures 7-9) do not consistently show a quicker drawdown of the water table in wells 5 and 14 than in wells 1, 2, 7, 9, 11, and 13. These findings suggest that the lower water table observed in wells 5 and 14 compared to the rest of the riparian zone is unlikely to be due to a rapid water table drawdown where drainage pipe D4 was located. Rather, data suggest that topography and storm characteristics are likely the reasons for the lower water level observed near well 5 and 14 during storms S1 and S3.

Another way that former drainage pipe locations could affect site hydrology is by generating a rapid water table 


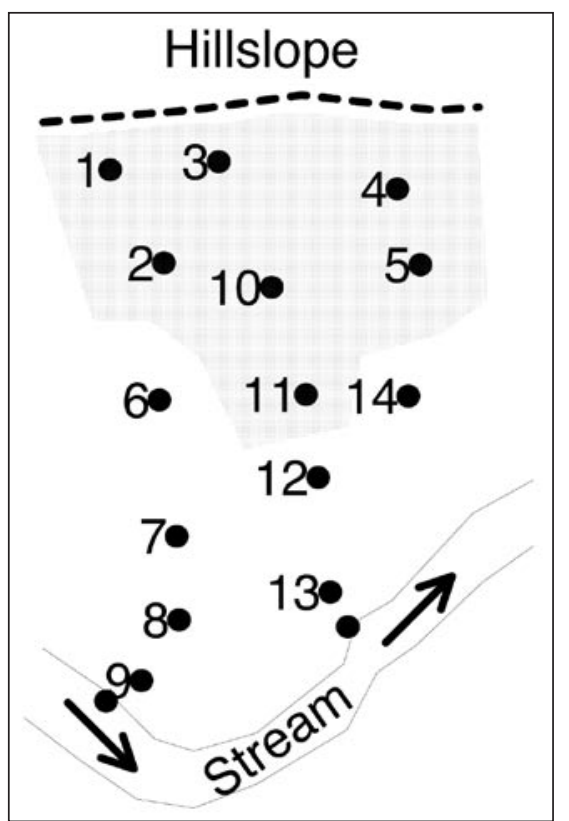

Figure 10. Map of the riparian wetland showing where the water table remains above $30 \mathrm{~cm}$ below ground surface for at least 14 consecutive days during the growing season (April 10-Oct 28) (area shaded in grey).

rise at one specific location in the riparian zone by allowing the quick transfer of water from one location to another during precipitation events. Water surface maps indicate a decrease in hydraulic gradient in the middle of the riparian zone for storms $\mathrm{S} 2$ and S4-S7 (Figures 8 and 9) compared to pre-storm conditions (Figure 8a) in an area around wells $2,10,11$, and 6 . This area corresponds to the area of the soil profile where loamy soil dominates near the surface, and therefore where a quick rise of the water table is likely to occur owing to finer soil texture. This area also corresponds to the small depression previously identified in the riparian zone (Figure 3). Runoff is likely to concentrate at this location, allowing a quicker rise of the water table at that location than in other riparian areas.

The former location of drain D3 connecting the slope bottom (wells 1 , 3 ) to the middle of the riparian zone (wells $2,10,11,6$ ) could also contribute to the quick rise of the water table in the middle of the riparian zone by acting as a preferential conduit toward the middle of the riparian zone for groundwater accumulating near the slope bottom during storms. However, if this were the case, this condition would persist long after precipitation stopped, since the water level in wells 1 and 2 remains high after precipitation ceases (Figure 6). This suggests that soil texture and topography are the likely reasons for the decrease in hydraulic gradient in the middle of the riparian zone during storms, rather than preferential flow along former drainage pipe locations (e.g., D3). Overall, data do not indicate that former drainage pipe locations affect the hydrology of the site either by acting as preferential conduit for groundwater flow or by allowing for a quick water table drawdown in some wells after precipitation events.

\section{Conclusion}

Our investigation of seasonal water table fluctuations and wetland delineation indicates that wetland hydrology has been reestablished in the riparian zone where soils are naturally poorly drained and where tile drains have been removed. Soil redox potentials in the 300 to $-200 \mathrm{mv}$ range also indicate that reducing or near-reducing conditions occur at the site most the year. This indicates that restoration was successful at reestablishing biogeochemical conditions typical of wetland soils, and that the technique of cutting the drainage pipes into several sections or removing them by hand and then compacting the disturbed soil back into place without adding extra material was appropriate for this site. Highresolution water table measurements during and after precipitation events do not indicate that the former drainage pipe locations still affect the hydrology of the site two years after removal. Water table monitoring during precipitation events also illustrates the three-dimensional character of water table fluctuations and the importance of using multiple transects of wells and piezometers when attempting to characterize wetland or riparian zone hydrology. We suggest that more studies documenting the success or failure of various hydrological restoration projects should be conducted for different wetland types in order to improve restoration techniques and enhance our ability to quickly and efficiently restore damaged wetlands.

\section{Acknowledgments}

We thank IndyParks, City of Indianapolis, and the Center for Earth and Environmental Science at Indiana University-Purdue University at Indianapolis for granting us access to the site. This research was supported by the School of Science at Indiana UniversityPurdue University at Indianapolis. We also thank R.J. Hunt, M. Ingram, and an anonymous reviewer for thorough reviews of this manuscript.

\section{References}

Andersen, H.E. 2004. Hydrology and nitrogen balance of a seasonally inundated Danish floodplain wetland. Hydrological Processes 18:415-434.

Baird, J.B. and S.W. Gaffney. 2000. Solute movement in drained fen peat: A field tracer study in a Somerset (UK) wetland. Hydrological Processes 14:2489-2503.

Duval, T.P. and A.R. Hill. 2006. Influence of stream bank seepage during lowflow conditions on riparian zone hydrology. Water Resources Research 42:W10425.

Goolsby, D.A. 2000. Mississippi basin nitrogen flux believed to cause Gulf hypoxia. EOS, American Geophysical Union, Transactions 81(29):321-327.

Harrison, W. 1963. Geology of Marion County, Indiana. Indiana Geological Survey Bulletin No. 28.

Hunt, R.J., T.D. Bullen, D.P. Krabbenhoft and C. Kendall. 1998. Using stable isotopes of water and strontium to investigate the hydrology of a natural and a constructed wetland. Ground Water 36:434-443.

Hunt, R.J., J.O. Jackson, G.L. Running, D.P. Krabbenhoft and J.T. Krohelski. 1999a. Hydrogeological, geomorphological, and vegetative investigations of select wetland creation and restoration projects. Wisconsin Department of Transportation Technical Report SPR-0092-45-91.

Hunt, R.J., J.F. Walker and D.P. Krabbenhoft, 1999b. Characterizing hydrology and the importance of ground-water discharge in natural and constructed wetlands. Wetlands 19:458-472. 
Jung M., T.P. Burt and P.D. Bates. 2004. Toward a conceptual model of floodplain water table response. Water Resources Research 40:W12409.

Mitsch, W.J., J.W. Day Jr., J.W. Gilliam, P.M. Groffman, D.L. Hey, G.W. Randall and N. Wang. 2001. Reducing nitrogen loading to the Gulf of Mexico from the Mississippi River Basin: Strategies to counter a persistent ecological problem. BioScience 51:373-388.

Mitsch W.J. and J.G. Gosselink. 2000. Wetlands, 3rd ed. New York: John Wiley and Sons.

National Oceanic and Atmospheric Administration (NOAA). 2002. Climatography of the United States No. 81. Monthly station normals of temperature, precipitation, and heating and cooling degree days 1971-2000.

. 2005. Climatological data, Indianapolis. http://www.crh.noaa.gov /ind/climatenormals.txt.

Sanders, L.L. 1998. A Manual Of Field Hydrology. Upper Saddle River, NJ: Prentice-Hall.

Schot, P.P. and M.J. Wassen. 1993. Calcium concentration in wetland groundwater in relation to water sources and soil conditions in the recharge area. Journal of Hydrology 141:197-217.
Sidle, W.C., D.L. Roose and V.T. Yzerman. 2000. Isotope evaluation of nitrate attenuation in restored and native riparian zones in the Kankakee watershed, Indiana. Wetlands 20:333-345.

Skaggs, R.W., D. Amatya, R.O. Evans and J.E. Parsons. 1994. Characterization and evaluation of proposed hydrologic criteria for wetlands. Journal of Soil and Water Conservation 49:501-510.

Thompson, C.A., E.A. Bettis and R.G. Baker. 1992. Geology of Iowa fens. Journal of Iowa Academy of Science 99:53-59.

U.S. Army Corps of Engineers. 1987. Corps of Engineers Wetland Delineation Manual. U.S. Army Corps of Engineers Technical Report Y-87-1.

Van den Bos, R. 2003. Restoration of former wetland in the Netherlands: Effect on the balance between $\mathrm{CO}_{2}$ sink and $\mathrm{CH}_{4}$ source. Netherlands Journal of Geosciences 82:325-332.

Vidon, P. and A.R. Hill. 2004a. Denitrification and patterns of electron donors and acceptors in 8 riparian zones with contrasting hydrogeology. Biogeochemistry 71:259-283.

2004b. Landscape controls on the hydrology of stream riparian zones. Journal of Hydrology 292:210-228.

Winter, T.C. 1992. A physiographic and climatic framework for hydrologic studies of wetlands: Aquatic ecosystems in semi-arid regions: Implications for resource management. Pages 127-148 in R.D. Robarts and M.L. Bothwell (eds), Aquatic ecosystems in semiarid regions: implications for resource management, N.R.H.I. Symposium Series 7. Saskatoon: Environment Canada.

2000. The vulnerability of wetlands to climate change: A hydrologic landscape perspective. Journal of the American Water Resources Association 36:305-311.

Philippe Vidon, Ph.D. Assistant Professor, Department of Earth Sciences, Indiana University, Purdue University, Indianapolis, 723 W Michigan St, SL130, India-

napolis, IN 46202-5132, 317/278-0722, pvidon@iupui.edu

Andrew P. Smith, M.S., Graduate Student, Department of Earth Sciences, Indiana University, Purdue University, Indianapolis, 723 W Michigan St, SL130, Indianapolis, IN 46202-5132 